\title{
EXPLORING ATTITUDES AND EXPECTATIONS OF INDONESIAN MUSLIM: A CASE OF UNTAPPED MARKET OF ISLAMIC PENSION FUND Yunice Karina $\mathbf{T}^{1^{*}}$, Ariza Ayumardani ${ }^{2}$, Hadri Kusuma ${ }^{3}$ \\ ${ }^{1 * 3}$ Accounting Department, Universitas Islam Indonesia; ${ }^{2}$ Ministry of Law and Human Rights, Indonesia. Email: ${ }^{*}$ yunice.karina@uii.ac.id, ${ }^{2}$ ariza.zahra@gmail.com, ${ }^{3}$ hkusuma@uii.ac.id Article History: Received on $20^{\text {th }}$ May 2020, Revised on $27^{\text {th }}$ June 2020, Published on $4^{\text {th }}$ July 2020
}

\begin{abstract}
Purpose of the study: This study aims to examine the factors of why the Muslim population is not having Islamic pension funds and to explore their expectation toward Islamic pension funds to make it a promising market in the near future.

Methodology: This study used a quantitative method with primary data through questionnaires distributed to 163 samples of the Muslim population in Indonesia. The Pearson correlation coefficient test is used to indicate normality and linearity. Meanwhile, the Kruskal Wallis test and two-tailed independent group t-tests are used to examine the hypotheses.
\end{abstract}

Main Findings: It is found that the low level of knowledge and trust toward Islamic pension funds are the two main reasons for not having Islamic pension funds. Meanwhile, the main society's expectation is to have the allowance from the government and simple administrative procedures by having an automatic enrolment set by the government. In addition to that, female and higher income group is found to have a better attitude and expectation toward Islamic pension fund.

Applications of this study: The study provides a descriptive picture for the Islamic pension fund provider and government to set a product based on the Muslim attitude and expectation.

Novelty/Originality of this study: As far as we are concerned, there is only a small number of research on analyzing the demand of Islamic Pension Fund particularly in the largest Muslim population, this work is an attempt to fill in this gap.

Keywords: Islamic Pension Fund, Attitude, Expectation.

\section{INTRODUCTION}

The number of Muslims is growing rapidly today. Based on Pew Research Center (2017), the number of Muslims is believed to be the best religious group in terms of growth. In decades later, it is projected that there will be an upward trend in the total global population, particularly the Muslim population. While the number of populations globally is predicted to climb by 32\% decades later, that of Muslims is projected to rise by $70 \%$. The population of Muslims in 2015 was $24,1 \%$ of the worldwide population, and in 2060 it is expected to be nearly one-third of the global population $(31,1 \%)$. This huge Muslim population is predicted to keep growing over the years.

Consequently, the number of Muslims may have an impact on the awareness of each individual for applying the whole rule from the Qur'an. Basically, Qur'an is based on Islamic principles and those principles are what dictate the laws of Islamic finance. The principle here called Sharia means the 'path to be followed'. As Muslims believe that Sharia is the best path coming from and going to Allah, they will feel obliged to strive for going on the path by implementing any instruction given in the Qur'an and Sunnah. The enthusiasm and awareness for applying Islamic principles grow rapidly as the consequences of the rising Muslim population.

Nowadays the Islamic principle-based products become well-known alternatives in the financial service sector. The Islamic financial service product which was highly recognized worldwide for a couple of decades is only the banking sector. However, its growth shows a significant decline from $49 \%$ in 2011 to $4 \%$ in 2015 which follows a $15 \%$ contraction in 2014. Therefore, other financial services including Islamic Pension Fund are needed to be explored to strengthen and sustain the Islamic finance industry. Reuters (2016) predicts the worldwide demand for the Islamic retirement fund is to climb up to US\$ 190 billion.

Otoritas Jasa Keuangan (2015), reveals that more than seven-in-ten $(74,8 \%)$ of workers and more than eight-in-ten $(85,7 \%)$ of entrepreneurs in Indonesia show interest for having Islamic Pension Fund. This interest applies to people who do not have pension funds or who have a conventional pension fund. Moreover, United Nations (2016) predicts the population of Indonesia, the largest home of the Muslim population worldwide, will expand to 322 million by 2050 with people aging over the 60 s will triple to 62 million. It shows a huge demand that has not been explored by the market player in this industry.

Nowadays pension funds have become an important part of public financial planning. The existence of long-term benefits and ultimate socialization would make people more interested in having pension funds. Based on Otoritas Jasa Keuangan (2017), there are four million people who have become participants of the Pension Fund Financial Institutions (DPLK). The number was significantly increased compared to the position in 2010 where the new DPLK participant was 2.8 million people. If counted with government-sponsored pension funds through the Social Security Administering 
Agency (BPJS) of Employment that has reached eight million people out of 250 million Indonesians, 5.6\% of the population or 14 million have retirement funds. The number of pension fund participants is projected to increase as a growing figure of the pension fund product including the Islamic Pension Fund.

The Islamic Pension Fund is more attractive after the release of the Indonesian Advisory Council (MUI) fatwa which provides Sharia funding opportunities to organize programs similar to annuity products. In this context, the design of operational activities of Islamic pension funds is no different from that in the conventional pension funds. It means that Islamic pension funds should manage and run pension programs that give a promise of pension benefits just like the conventional pension funds. Based on sharia principles, the Islamic pension fund is an implementation of the teachings of Islam to manage wealth in good times to be used in times of need. In addition to that, OJK also released its regulation Number 33/POJK.05/2016 about Islamic Pension Fund. Under this regulation, pension plans can be organized on the basis of sharia principles in several ways including the new establishment or the conversion.

Previous literature has proven an important role of attitude, including a study conducted by Wang, et al. (2008) which found attitude as one of the most important factors in determining consumer acceptance. A study conducted by Ajzen (1991); Ajzen \& Fishbein (1980); and Smith et al. (2008) found that attitude has long been admitted to have intense correlations with intention and significant role in the forming of behavior. Armitage \& Conner (2001) present a metaanalytic study of 185 papers of planned behavior theory that outlined a significant influence of attitudes in the straight forming of intention in cooperation with the instinctive norm and perceived behavior control.

In the context of Islamic financial products, most studies including Gait \& Worthington (2008) and Loo (2010) have been carried out to reveal the importance of attitudes and expectations toward Islamic banking. A study conducted by Ramdhony (2013) obtained that $82 \%$ of respondents have awareness of Islamic financial products and outlined a significant correlation between public awareness and religious belief. This study determined that $66 \%$ of the respondents have more motivation in Islamic financial products in line with their religious belief, the more pious people the more familiar with Islamic financial products they will be.

Meanwhile, another study conducted by Buchari, et al. (2015) found that more than half (56\%) of total respondents are aware of the Islamic financial products and believe that the products are unique and have the empathy of dealing with the other mankind. Based on the above scheme, the demand for Islamic Pension Fund is predicted to be raised as much as the great number of Muslims in the world. This paper used primary data with 163 questionnaires spread through online surveys. It aims to examine the attitudes and expectations of the Muslim population in Indonesia toward the Islamic Pension Fund as well as its role of demographic factors. It is expected to discover the reason beyond the small number of Islamic Pension Fund unless the fact of rising the demand of Islamic Pension Fund (Otoritas Jasa Keuangan, 2015).

The significance of this study can be seen in at least two viewpoints. First, as far as it can be ascertained, there is no available data/research concerning the attitude and expectation towards the Islamic pension fund. This study aims to fill this gap. Second, this study focuses on a country where the most populated Muslims worldwide existed and usually wellknown as a "hidden treasure" (Wilson et al., 2013). Taking into account the rapid increase of the Muslim population and the flourishing demand of Sharia-based pension funds in the world, this research aims to explore the attitude and expectation of the Indonesian Muslim population toward this potential yet untapped market.

This study begins with the background of the study which is followed by the literature review relevant to this study as well as the development of the hypothesis. After that, it presents the research method and the result. Finally, it concludes with a summary, limitation, and recommendation for further research.

\section{LITERATURE REVIEW}

\section{Theory of Planned Behavior}

The research model used in this study is based on the Theory of Planned Behavior (TPB) (Ajzen, 1991). TPB is a theory developed by Ajzen which is an extended study of the Theory of Reasoned Action (TRA) proposed by Fishbein \& Ajzen (1975). The main focus of TPB is similar to the Theory of Reasoned Action, which examines the intention of individuals to perform certain behaviors. The intention is considered to be able to show motivational factors that influence behavior. The intention is an indication of how bad people want to attempt and how much effort will be spent by individuals to perform a behavior. According to Ajzen \& Fishbein (2005), there are three factors that can predict individual intentions in carrying out certain behaviors, namely attitudes, subjective norms, and perceived behavioral control. Attitude is the individual's positive or negative evaluation of certain behaviors. Whereas subjective norms are one's perceptions of social pressure to do or not do certain behaviors Fishbein \& Ajzen (1975). Lastly, perceived behavioral control is an individual's perception of the control they have in connection with certain behaviors (Ajzen \& Fishbein, 2005). In this study, we integrate the subject norms and perceived control over behavior into a single variable called expectation, which then combined with attitude to be examined.

To the best of the authors' knowledge, TPB has yet to be applied towards the participation of the Islamic pension fund. However, some researchers have applied the TPB in the context of conventional retirement planning (Foster, 2017; Macleod et al., 2012). To illustrate this, Foster (2017) utilizes TPB to explore opportunities and attitudes of young 
people for having pensions and to identify numerous factors affecting pension contributions, which include knowledge, trust, and advice from the surroundings. Meanwhile, Siang \& Weng (2011) found a result in line with TPB which reveals that attitudes, subjective norms, and perceived behavioral control are significant to predict the intention to adopt the products and services from Islamic banking. Attitude is the most important factor to assess the intention to adopt Islamic banking for non-Muslim consumers in Malaysia.

The most important role of attitude is that it predicts intention and ultimately behavior. Some researchers believe that attitude is an expression and feeling of someone who shows their likes or dislikes towards an object at a very initial stage (Priester, et al., 2004). Studying one's attitude is the best way to understand why consumers take certain actions or in a specific context of whether or not they will purchase a product or not as mentioned by Wicker (1969). Further, it might predict one's purchasing power.

Meanwhile, the expectations defined as pre-experience beliefs of an actual experience yet to come (Oliver \& Winer, 1987), they hold a crucial role in making decisions with regard to the uncertain future (Robledo, 2001). He further explains that managing the customer's expectations becomes an important part of ensuring customer satisfaction particularly for customers with relatively little experience with the service. Coye (2004) argues that the importance of fulfilling customer expectations should encourage market players to be aware of their customer expectations.

In the context of a religion-related product, especially Islamic banking, there is strong confidence that attitudes and expectations will simultaneously influence behavior. Whereas, attitude and expectation toward retirement have been found to be important in one's planning for retirement fund (Atchley, 2000; Walker, et al., 1981). However, there have been few systematic efforts to explore those factors in one's planning for retirement fund which based on the Sharia principle.

\section{Hypothesis Formulation}

a. Gender

In terms of financial literacy, Clark-Murphy \& Gerrans (2001) found that women have more financial knowledge than men as women are having more time and getting more exposure to discuss with a financial professional. Similar to prior research including Bajtelsmit, et al. (1999); Clark, et al. (2007); and Papke (1998) found that men are more risk-tolerant than women. Men tend to manage their financing in the short term and riskier financial choices, while women tend to manage to finance for the long term and less-risky financial choices as it will be brought closer to sustainability. It is in line with the study conducted by Clark and Strauss (2008) that men are overconfident when it comes to gaining a maximum return for the sacrifice of a big risk. This men's perception is also reflected in the culture of Muslim society, thus it will lead the men to have a lower attitude and expectation toward pension funds including the Sharia one.

\section{$\mathrm{H}_{1}$ : There are a different attitude and expectation towards Islamic Pension Fund between male and female group.}

\section{b. Age}

Bernheim (1992) reveals that people only saved one-third of the total amount required to have a comfortable postworking life. As a matter of fact, Warshawsky and Ameriks (2016) indicated that 50\% of people between 25-71 years is not having enough funds to fulfill their needs during the retirement period. In several emerging countries, the pension fund market is not well-maintained by the government and left untapped (Szinovacz, 2003). Further, Szinovacz (2003) found that young people aged below 30 assume that it is too early to think of saving for the pension fund. Meanwhile, those who are in their 30 and 40 years old believe that they have prepared well for the post-working period as they already had the retirement saving yet the sad reality is that most people at age 55 could not be able to properly retire due to the late preparation for retirement.

\section{$\mathrm{H}_{2}$ : There are different attitude and expectation towards Islamic Pension Fund among age groups.}

\section{c. Income}

Other than the demography factor such as gender and age, one's income and wealth are also believed to have a significant positive effect on pension funds (Clark-Murphy and Gerrans, 2001; Warshawsky and Ameriks, 2016). In addition to that, Kim, Kwon, \& Anderson (2005) reveals that higher individual's retirement is usually found in people who are working and owning more savings. Working people tend to have better financial literacy supported by their workplace. A positive relationship between income and responsible is explained in financial management behavior which reveals that the higher the income, the better and more responsible the financial behavior (Power \& Hira, 2004).

\section{$\mathrm{H}_{3}$ : There is different attitude and expectation towards Islamic Pension Fund among income groups.}

\section{METHODOLOGY}

\section{Research Design}

A quantitative method is used in this study to diagnose trends and to find the comprehensive explanations for correlations among given variables as stated by Creswell (2012). For assessing the demographic and independent 
variables, this study adopts both descriptive and inferential analyses. The instruments formulated in nominal and interval scale in which the overall of group responses is examined. The reliability test is used in order to know whether this study will construct steady or consistent findings or not in the future, different schemes, and under different circumstances by using Cronbach's alpha values.

The reliability test for both attitude and expectation resulted in a score of 0.753 and 0.929 respectively. These scores are higher than 0.70 which means that this study is reliable. Meanwhile, the measurement of the relationship between variables is done by using Pearson correlations. Bryman \& Cramer (2002) stated that the Pearson correlation coefficient is indicating normality and linearity. Pearson has ranged between -1.0 to 1.0 indicating the strength of the linear relationship. According to the Pearson correlation, the attitude and expectation towards Islamic Pension Fund have a positive correlation of 0.523 which indicates the variable is significantly correlated with another variable.

Pearson correlation coefficient is used to point out normality and linearity and in order to determine the effect of demographic variables (Bryman \& Cramer, 2002). Furthermore, the Kruskal-Wallis test and a series of two-tailed independent group t-tests are used to examine the hypotheses.

\section{Questionnaire and Sample Frame}

A convenient random sampling is used in this study. The respondents are Indonesian Muslim citizens aging from 18 to 64. A total of 250 questionnaires are distributed through an electronic survey system but only 163 of them are wellresponded. Considering the target sample of this study was non-native English speakers, consequently, the Indonesian translation of each detail, instruction, and question were also presented in the survey.

Respondents were mandatory to answer a series of questions in the form of a questionnaire divided into three sections and consisted of 34 questions. In Section A, 12 questions were given to determine the respondent's demographic profiles.

Respondents were grouped by age, sex, level of education, marital status, etc. In Section B, 11 questions were given to determine the level of their attitude towards the Islamic pension fund. In Section C, another set of 11 questions was given to determine the level of their expectation towards the Islamic pension fund. Each question is scaled in which the higher score values indicate a positive attitude/expectation about the Islamic pension fund. A five-point Likert Scale in which 5 is to represent strongly agree and 1 is to represent strongly disagree was used to compute the response of the respondents.

\section{RESULTS/FINDINGS}

\section{Demographic Profile}

The demographic profile consists of gender, age, marital status, number of dependents, monthly income and etc. Out of 163 respondents, there are 80 male and 83 female respondents. The respondents' age distributions as $59.50 \%$ are in the range between 18 to 24 years old, followed by $26.38 \%$ in the range between 25 to 30 years old, then $7.97 \%$ are between 31 to 40 years old, followed by $3.68 \%$ between 41 and 50; lastly, $2.45 \%$ of them are in range 51 to 64 years old. For the marital status, $77.91 \%$ are single, $21.47 \%$ are married, and $0.006 \%$ are divorced. Examining the number of dependants, $63.8 \%$ of respondents have no dependants, $9.2 \%$ have only one dependant, $25.15 \%$ have two to five dependants, and the last $1.84 \%$ have more than five dependants.

As a type of occupation, full-time employees have the highest score for $53.98 \%$, followed by $25.76 \%$ as unemployed, $10.42 \%$ as self-employed, and the last $9.81 \%$ as part-time employees. For the monthly income, $46.62 \%$ has income less than 3 million rupiahs, and 39.26\% respondent has an income between 3 million to 6 million rupiahs. As $12.26 \%$ of respondents have income between 6 million to 10 million rupiahs, the rest of respondents $1.84 \%$ have the highest income of more than 10 million rupiahs. These proportion resulted because most of our respondents just started their careers and still in the beginner or middle level.

\section{Descriptive Data}

As found in the result of the questionnaire collected it shows the responses of 163 respondents on the attitude and expectations towards the Islamic Pension Fund. We analyze further for the hindering factors as we concern more on the untapped market of the Islamic Pension Fund. For the respondents currently do not have an Islamic Pension Fund, Table 1 is the highlighted response. Table 1 also presents the respondents that have some expectations towards Islamic Pension Fund.

Table 1: Attitude and Expectation toward Islamic Pension Fund

\begin{tabular}{llllllll}
\hline Attitude & \multicolumn{6}{c}{ Expectation } & Median \\
\hline Questions & Mean & $\begin{array}{l}\text { Standard } \\
\text { Deviation }\end{array}$ & Median & Questions & Mean & $\begin{array}{l}\text { Standard } \\
\text { Deviation }\end{array}$ & \\
\hline Q1 & 0.54 & 0.145 & 0.56 & Q1 & 0.71 & 0.161 & 0.61 \\
\hline
\end{tabular}




\begin{tabular}{llllllll}
\hline Q2 & 0.54 & 0.185 & 0.44 & Q2 & 0.75 & 0.172 & 0.95 \\
\hline Q3 & 0.76 & 0.243 & 0.48 & Q3 & 0.81 & 0.201 & 0.70 \\
\hline Q4 & 0.76 & 0.235 & 0.48 & Q4 & 0.80 & 0.184 & 0.63 \\
\hline Q5 & 0.55 & 0.186 & 0.34 & Q5 & 0.83 & 0.206 & 0.57 \\
\hline Q6 & 0.31 & 0.196 & 0.24 & Q6 & 0.84 & 0.210 & 0.52 \\
\hline Q7 & 0.56 & 0.191 & 0.41 & Q7 & 0.86 & 0.212 & 0.48 \\
\hline Q8 & 0.64 & 0.238 & 0.25 & $\mathbf{Q 8}$ & 0.86 & 0.216 & 0.42 \\
\hline Q9 & 0.61 & 0.156 & 0.55 & $\mathbf{Q 9}$ & 0.86 & 0.218 & 0.41 \\
\hline Q10 & 0.63 & 0.223 & 0.37 & $\mathbf{Q 1 0}$ & 0.83 & 0.209 & 0.52 \\
\hline Q11 & 0.69 & 0.153 & 0.32 & $\mathbf{Q 1 1}$ & 0.81 & 0.178 & 0.72 \\
\hline
\end{tabular}

Source: Data Processed

\section{Hypothesis Test}

This section presents the results of the hypotheses tests. Table 2 shows the comparison results of attitudes toward the Islamic Pension Fund while table 3 indicates the different expectations toward Islamic Pension Fund.

Table 2: Results of the Inferential Test of Attitudes

\begin{tabular}{|c|c|c|c|c|}
\hline Criteria & & Mean Rank & Significance & $\begin{array}{l}\text { Hypothesis } \\
\text { Test }\end{array}$ \\
\hline \multirow{2}{*}{ Gender } & Male & 3.5661 & \multirow{2}{*}{0.002} & \multirow{2}{*}{ Supported } \\
\hline & Female & 3.5693 & & \\
\hline \multirow{5}{*}{ Age } & 51-64 & 81.13 & \multirow{5}{*}{0.417} & \multirow{5}{*}{ Rejected } \\
\hline & $41-50$ & 79.17 & & \\
\hline & $31-40$ & 71.96 & & \\
\hline & $25-30$ & 74.86 & & \\
\hline & $18-24$ & 84.87 & & \\
\hline \multirow[t]{4}{*}{ Income } & $\begin{array}{l}\text { Less } \\
\text { than } 3 \\
\text { million }\end{array}$ & 71.98 & \multirow{4}{*}{0.015} & \multirow{4}{*}{ Supported } \\
\hline & $\begin{array}{l}3-6 \\
\text { million }\end{array}$ & 77.21 & & \\
\hline & $\begin{array}{l}6-10 \\
\text { million }\end{array}$ & 86.84 & & \\
\hline & $\begin{array}{l}\text { More } \\
\text { than } 10 \\
\text { million }\end{array}$ & 128.5 & & \\
\hline
\end{tabular}

Source: Data Processed

Table 3: Results of the Inferential Test of Expectations

\begin{tabular}{|c|c|c|c|c|}
\hline \multicolumn{2}{|c|}{ Criteria } & $\begin{array}{l}\text { Mean } \\
\text { Rank }\end{array}$ & Significance & $\begin{array}{l}\text { Hypothesis } \\
\text { Test }\end{array}$ \\
\hline \multirow{2}{*}{ Gender } & Male & 4.0502 & \multirow{2}{*}{0.007} & \multirow{2}{*}{ Supported } \\
\hline & Female & 4.0825 & & \\
\hline \multirow{5}{*}{ Age } & $51-64$ & 80.75 & \multirow{5}{*}{0.618} & \multirow{5}{*}{ Rejected } \\
\hline & $41-50$ & 95.67 & & \\
\hline & $31-40$ & 97.38 & & \\
\hline & $25-30$ & 84.27 & & \\
\hline & $18-24$ & 78.14 & & \\
\hline \multirow[t]{4}{*}{ Income } & Less than 3 million & 95.94 & \multirow{4}{*}{0.003} & \multirow{4}{*}{ Supported } \\
\hline & 3-6 million & 71.11 & & \\
\hline & 6-10 million & 70.13 & & \\
\hline & More than 10 million & 40.33 & & \\
\hline
\end{tabular}

Source: Data Processed 
T-test also called a two-sample t-test, is used to test the differences between the means of gender groups. The result 1of the analysis is reported as a $p$-value. Based on the T-Test results shown in Table 2 and 3, it was found that the Female respondents have better attitudes and expectations towards Islamic Pension Fund than Male respondents. Yet, the differences are statistically significant since the $p$-value is 0.002 (Table 2) for attitude and 0.007 (table 3 ) for expectation which are less than 0.05 . Thus, the $\mathrm{H}_{1}$ stating there is different attitudes and expectations towards Islamic Pension Fund between male and female is supported.

A Kruskal-Wallis test was used to determine whether the differences exist for the average weighted means of more than two groups. That does not differ from the T-test. The responses of the respondents when grouped according to age, income and type of employment/number of defendants will reflected in the dependent variable, attitudes and expectations. As depicted in Table 2 and 3, by grouping the respondents according to their age, those with the age from 18 to 24 years old have better attitudes and expectations towards Islamic Pension Fund, followed by the respondents from 51 to 60 years, then the respondents from 41 to 50 years old, then respondents from 25 to 30 years old, lastly respondents from 31 to 40 years old have the lowest attitudes and expectations towards Islamic Pension Fund. However, the differences are not statistically significant for both attitude and expectation since the p-value is above 5\% (0.417 and 0.618 respectively). Thus, there are no different attitudes and expectations towards Islamic Pension Fund among the age group.

As depicted in Table 3, by grouping the respondents are grouped according to their income, those with an income worth more than 10 million have best attitudes and expectations towards Islamic Pension Fund, followed by the respondents with an income less than 3 million, the respondents with an income from 3 to 6 million, and then the respondents with an income from 6 to 10 million. More interestingly, the differences are statistically significant since the p-value is below 5\% ( 0.0153 for attitude and 0.003 for expectation), thus there is different attitudes and expectations towards Islamic Pension Fund among income group.

\section{DISCUSSION}

Based on findings, untapped markets of the Islamic Pension Fund rely on the awareness and trust of the respondents. As illustrated in Table 1 , for the attitude, the highest weighted average is 0.76 for the absence of knowledge and trust towards the Islamic Pension Fund. Here, the knowledge and trust of the Islamic Pension Fund have a role in determining their plan for the pension fund. Dvorak and Hanley (2010) found that "participants have a fairly good understanding of the basic mechanism of the pension plan but they have insufficient knowledge to differentiate among numerous investment options". "The future time perspective, financial knowledge, and financial risk tolerance are important variables when it comes to understanding individuals' retirement saving practices" (Jacobs-Lawson and Hershey, 2005).

In a related Australian study, Gallery, et al. (2011) investigated financial literacy variability using a comprehensive survey of public sector superannuation fund members. Generally, it is found that despite a pretty good financial literacy related to investment in general, the literacy of specific investment was relatively low. "Wealth and household income are also identified as being positively related to investment knowledge. They highlight the importance of improving financial literacy through the use of education programs to prevent uninformed decisions that lead to unexpected and undesirable financial outcomes".

A survey from ANZ (2011) reveals that "lack of financial literacy is responsible for a third of the respondents who reported difficulty in understanding their superannuation statements". Financial literacy here refers to knowledge and understanding. Otoritas Jasa Keuangan (2017) reports that the level of literacy of pension fund in Indonesia is merely $10.9 \%$ and the level of inclusion of pension fund products is merely $4.6 \%$. It is clearly seen that the education and literacy of pension funds is an unsolved problem in Indonesia and many other countries worldwide. "Financial literacy is very low around the world, irrespective of the level of financial market development and the type of pension provision (Lusardi and Mitchell, 2011)".

Put it in the context of Indonesia, MasterCard (2015) reports that Indonesia is ranked at $10^{\text {th }}$ position with an overall score of 62. The best improvement is shown in 'Financial Planning', went up from 70 to 78 points yet the downward trend is also shown in the 'Investment' component which went down from 55 to 47 . A new trend of the prudence of Indonesian society in Financial Planning emerged as it reported an increase of 8 points in the 'Financial Planning' category, which jumped the rank from $13^{\text {th }}$ to $5^{\text {th }}$. "This could be a result of the insecurity in terms of income and employment prospects arising from the economic slowdown and tight labour market conditions recently. These conditions may be the driving force behind Indonesians being particularly prudent in financial planning, feeling the need to save regularly and set aside emergency savings, as well as develop an attitude of starting to save early, regardless of how wealthy they are".

On the other side, as illustrated in Table 2, for expectation, the highest weighted average is 0.86 to expect the allowance from the government and simple administrative procedure. Automatic enrolment would be one of the best facility government could provide to invite more people to go for the Islamic pension fund. As we know, at this time, there is no Sharia-compliant pension fund provided by the government which brings a real obstacle for society to save for the Islamic pension fund. With regard to this matter, the government needs to take into account of all the possible ways to facilitate the society. 
This study proves the significant effect of gender and income to decide for the Islamic pension fund and its determinants. Another personal characteristic, age, is found to be an insignificant factor. "Women are more sensitive to the choice of Islamic pension fund than men. Service quality, trust, and Sharia compliance had a greater influence on women's choice of the Islamic pension fund. Islamic financial institutions should thus adopt gender as the main criterion of client segmentation and classification. Our results are consistent with the results of other studies indicating that women are more likely to comply (Sistrunk \& McDavid, 1971) and are thus more impressionable than men (Aronson, 2004; Ltifi, et al., 2016)."

The contributions of our study may attract interest from other researchers as well as managers and practitioners. As for the practical implication, this research triggers the prominent players in the Sharia-compliant pension market to consider these factors including the Word of Mouth Marketing, quality of service offered to customers, trust, and Sharia compliance. These factors are taken into the consideration of a majority of the customer in choosing a financial product/service. Further, this study also helps managers and key stakeholders of Islamic Pension corporations to better understand the customers by achieving the competitive advantage and creating value for customers. For we have successfully identified two main customer segments with different expectations, the players of the Islamic pension fund can develop specific product and communication strategies.

\section{CONCLUSION}

Indonesian Muslim attitude and expectation towards pension funds show that Islamic Pension Fund should be more developed in several aspects. More than $60 \%$ of respondents disagree that they do not need Islamic Pension Fund which shows a positive attitude toward Islamic Pension Fund. However, 61.02\% of respondents showed that they do not know about Islamic Pension Fund. Consequently, almost 50\% of respondents expected massive socializations, better and easier facility, clear and transparent management and other good expectations towards Islamic Pension Fund. Statistically, it is also found that there are significant differences to gender and income level against the attitude and expectation toward Islamic Pension Fund, while age has an insignificant difference.

The findings of the research convey the standard of Muslim's attitude and expectation toward the Islamic Pension Fund in Indonesia which could also be the reflection for Muslim countries worldwide. This information will be useful for solving the huge gap between the demand and supply of the Islamic Pension Fund since it will help to raise the awareness of market players and society to see the Islamic Pension Fund as a promising and prospective industrial sector in the foreseeable future. For the acceleration of this industry, this study suggests the government to formulate a supportive regulation which triggers Indonesia's Social Security Agency (BPJS) to offer the Sharia-compliant plan. The national program is believed to push the private insurance companies to promote the plan a way better than what they are doing right now. The market players of the Islamic pension fund should market their products more attractively and provide better service for the potential customer. Even further, corporate could provide auto-enrolment for those who are willing to have Sharia-compliant retirement planning. As an early movement, it might start with women and highincome society which are found to be more interested in the Islamic pension fund.

\section{LIMITATION AND STUDY FORWARD}

This study comprises of a few restraints such as: (i) the determined population that limit to Indonesian Muslim society and (ii) the sample scattering did not evenly represent the whole territory of Indonesia. Consequently, the final result may not ideally represent the population in the area. The imminent researchers could probably add more variables of gauging the attitude and expectation of prospective customers, and also encompassing more amount of sample of the study.

\section{AUTHORS CONTRIBUTION}

All co-authors contribute a sizeable work to the article. The first author was responsible for proposing the research idea as well as exploring the existing literatures to be the basis for formulating the hypothesis and discussion of this study. The second author was responsible for analysing the data and providing the interpretation of the analysis result. The third author was responsible for concluding and reviewing the whole paper.

\section{REFERENCES}

1. Ajzen, I., \& Fishbein, M. (1980). Understanding attitudes and predicting social behavior. Englewood Cliffs, NJ: Prentice-Hall

2. Ajzen, I. (1991). The theory of planned behavior. Organizational Behavior and Human Decision Processes, 50(2), 179-211. https://doi.org/10.1016/0749-5978(91)90020-T

3. Ajzen, I., \& Fishbein, M. (2005). The Influence of Attitudes on Behavior. In D. Albarracín, B. T. Johnson, \& M. P. Zanna (Eds.). The Handbook of Attitudes. Lawrence Erlbaum Associates Publishers.

4. ANZ. (2011). Adult Financial Literacy in Australia. Retrieved from www.anz.com/cr

5. Armitage, C. J., \& Conner, M. (2001). Efficacy of the Theory of Planned Behavior: a meta-analytic review. The British Journal of Social Psychology, 40(Pt 4), 471-499. https://doi.org/10.1348/014466601164939

6. Aronson, E. (2004). The Social Animal. Worth Publishers.

7. Atchley, R. C. (2000). Social forces and aging : an introduction to social gerontology. Wadsworth. 
8. Bajtelsmit, V. L., Bernasek, A., \& Jianakoplos, N. A. (1999). Gender differences in defined contribution pension decisions. Financial Services Review, 8(1), 1-10. https://doi.org/10.1016/S1057-0810(99)00030-X

9. Bernheim, B. D. (1992). Is the Baby Boom Generation Preparing Adequately for Retirement | Scinapse | Academic search engine for paper\}. New York: Merrill Lynch and Company. Retrieved from https://scinapse.io/papers/1223287420

10. Bryman, A., \& Cramer, D. (2002). Quantitative Data Analysis with SPSS Release 10 for Windows. New York: Routledge. https://doi.org/10.4324/9780203471548

11. Buchari, I., Rafiki, A., Hadi, A., \& Qassab, A. (2015). Awareness and attitudes of employees towards islamic banking products in Bahrain. Procedia Economics and Finance, 30, 68-78. https://doi.org/10.1016/S22125671(15)01256-3

12. Clark-Murphy, M., \& Gerrans, P. (2001). Consultation and resource usage in retirement savings decisions: Australian evidence of systematic gender differences. Financial Services Review, 10(1-4), 273-290. https://doi.org/10.1016/S1057-0810(01)00086-5

13. Clark, G. L., Caerlewy-Smith, E., \& Marshall, J. C. (2007). The consistency of UK pension fund trustee decision-making. Journal of Pension Economics and Finance, 6(01), 67. https://doi.org/10.1017/S1474747206002629

14. Clark, G. L., \& Strauss, K. (2008). Individual pension-related risk propensities: the effects of sociodemographic characteristics and a spousal pension entitlement on risk attitudes. Ageing and Society, 28(06), 847-874. https://doi.org/10.1017/S0144686X08007083

15. Coye, R. W. (2004). Managing customer expectations in the service encounter. International Journal of Service Industry Management, 15(1), 54-71. https://doi.org/10.1108/09564230410523330

16. Creswell, J. W. (2012). Educational research: planning, conducting, and evaluating quantitative and qualitative research. Pearson.

17. Dvorak, T., \& Hanley, H. (2010). Financial literacy and the design of retirement plans. Journal of Behavioral and Experimental Economics (Formerly The Journal of Socio-Economics), 39(6), 645-652. https://doi.org/10.1016/j.socec.2010.06.013

18. Fishbein, M. A., \& Ajzen, I. (1975). Belief, attitude, intention and behavior: An introduction to theory and research. Reading: Addision-Wesley.

19. Foster, L. (2017). Young People and Attitudes towards Pension Planning. Social Policy and Society, 16(01), 65-80. https://doi.org/10.1017/S1474746415000627

20. Gait, A., \& Worthington, A. (2008). An empirical survey of individual consumer, business firm and financial institution attitudes towards Islamic methods of finance. International Journal of Social Economics, 35(11), 783-808. https://doi.org/10.1108/03068290810905423

21. Gallery, N., Gallery, G., Brown, K., Furneaux, C., \& Palm, C. (2011). Financial Literacy and Pension Investment Decisions. Financial Accountability \& Management, 27(3), 286-307. https://doi.org/10.1111/j.1468-0408.2011.00526.x

22. Jacobs-Lawson, J. M., \& Hershey, D. A. (2005). Influence of future time perspective, financial knowledge, and financial risk tolerance on retirement saving behaviors. Financial Services Review, 14. Retrieved from https://pdfs.semanticscholar.org/0704/e9dd97a3481b433b31b41ee48c630218ff67.pdf

23. Kim, J., Kwon, J., \& Anderson, E. A. (2005). Factors Related to Retirement Confidence: Retirement Preparation and Workplace Financial Education. Financial Counseling and Planning, 16(2), 77-89.

24. Loo, M. (2010). Attitudes and Perceptions towards Islamic Banking among Muslims and Non-Muslims in Malaysia: Implications for Marketing to Baby Boomers and X-Generation. International Journal of Arts and Sciences, 3(13), 453-485.

25. Ltifi, M., Hikkerova, L., Aliouat, B., \& Gharbi, J. (2016). The determinants of the choice of Islamic banks in Tunisia. International Journal of Bank Marketing, 34(5), 710-730. https://doi.org/10.1108/IJBM-11-2014-0170

26. Lusardi, A., \& Mitchell, O. (2011). Financial Literacy around the World: An Overview. National Bureau of Economic Research. https://doi.org/10.3386/w17107

27. Macleod, P., Fitzpatrick, A., Hamlyn, B., Jones, A., Kinver, A., \& Page, L. (2012). Attitudes to Pensions: The 2012 Survey. London.

28. MasterCard Research. (2015). MasterCard Index of Financial Literacy Report (2013H1). Retrieved from https://www1.mastercard.com/content/intelligence/en/research/reports/2013/mastercard-index-of-financialliteracy-report-2013h1.html

29. Oliver, R. L., \& Winer, R. S. (1987). A framework for the formation and structure of consumer expectations: Review and propositions. Journal of Economic Psychology, 8(4), 469-499. https://doi.org/10.1016/01674870(87)90037-7

30. Otoritas Jasa Keuangan. (2015). Roadmap IKNB Syariah 2015-2019. Retrieved from www.ojk.go.id

31. Otoritas Jasa Keuangan. (2017). Pension Fund Statistics. Retrieved from www.ojk.go.id

32. Papke, L. E. (1998). How Are Participants Investing Their Accounts in Participant Directed Individual Account Pension Plans? The American Economic Review, 88, 212-216. https://doi.org/10.2307/116921

33. Pew Research Center. (2017). Why Muslims are the world's fastest-growing religious group | Pew Research Center. Pew Research Center. Retrieved from http://www.pewresearch.org/fact-tank/2017/04/06/why-muslims- 
are-the-worlds-fastest-growing-religious-group/

34. Power, M. L., \& Hira, T. K. (2004). University-Provided Retirement Planning Support and Retiree Financial Satisfaction During Retirement: Differences by Gender, Job Classification, and Planning Behavior. Risk Management and Insurance Review, 7(2), 121-149. https://doi.org/10.1111/j.1098-1616.2004.00041.x

35. Priester, J. R., Nayakankuppam, D., Fleming, M. A., \& Godek, J. (2004). The A2SC2 Model: The Influence of Attitudes and Attitude Strength on Consideration and Choice. Journal of Consumer Research, 30(4), 574-587. https://doi.org/10.1086/380290

36. Ramdhony, D. (2013). Islamic Banking Awareness Attitudes and Bank Selection Criteria. International Journal of Humanities and Applied Sciences (IJHAS)., 29-35.

37. Reuters, T. (2016). State of the Global Islamic Economy. Global Islamic Economy Report. https://doi.org/10.1017/CBO9781107415324.004

38. Robledo, M. A. (2001). Measuring and managing service quality: integrating customer expectations. Managing Service Quality: An International Journal, 11(1), 22-31. https://doi.org/10.1108/09604520110379472

39. Siang, L. C., \& Weng, L. K. (2011). Factors Affecting Non-Muslim Consumers' towards Intention to use Islamic Banking Products and Services. In Las Vegas International Academic Conference.

40. Sistrunk, F., \& McDavid, J. W. (1971). Sex variable in conforming behavior. Journal of Personality and Social Psychology, 17(2), 200-207. https://doi.org/10.1037/h0030382

41. Smith, J. R., Terry, D. J., Manstead, A. S. ., Louis, W. R., Kotterman, D., \& Wolfs, J. (2008). The AttitudeBehavior Relationship in Consumer Conduct: The Role of Norms, Past Behavior, and Self-Identity. The Journal of Social Psychology, 148(3), 311-334. https://doi.org/10.3200/SOCP.148.3.311-334

42. Szinovacz, M. (2003). Contexts and pathways: Retirement as an institution, process and experience. In G. A. Adams (Ed.), Retirement: Reasons, Processes, and Results.

43. United Nation. (2016). Indonesia: Govt to introduce Islamic pension funds. Retrieved October 24, 2017, from http://www3.asiainsurancereview.com/News/View-NewsLetter-Article?id=35659\&Type=eDaily\#

44. Walker, J. W., Kimmel, D. C., \& Price, K. F. (1981). Retirement Style and Retirement Satisfaction: Retirees Aren't All Alike. The International Journal of Aging and Human Development, 12(4), 267-281. https://doi.org/10.2190/ABAU-8BLY-32N6-K8A9

45. Wang, G., Dou, W., \& Zhou, N. (2008). Consumption attitudes and adoption of new consumer products: a contingency approach. European Journal of Marketing, 42(1/2), 238-254. https://doi.org/10.1108/03090560810840998

46. Warshawsky, M. S., \& Ameriks, J. (2016). How prepared are Americans for retirement? In Olivia S. Mitchell \& Richard C. Shea (Eds.), Reimagining Pensions: The Next 40 Years. Oxford University Press.

47. Wicker, A. W. (1969). Attitudes versus Actions: The Relationship of Verbal and Overt Behavioral Responses to Attitude Objects. Journal of Social Issues, 25(4), 41-78. https://doi.org/10.1111/j.1540-4560.1969.tb00619.x

48. Wilson, J. A. J., Belk, R. W., \& Scott, L. (2013). Crescent marketing, Muslim geographies and brand Islam. Journal of Islamic Marketing, 4(1), 22-50. https://doi.org/10.1108/17590831311306336 